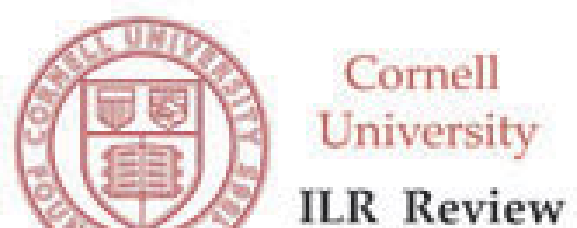

The Earnings Effects of Sexual Orientation

Author(s): Dan A. Black, Hoda R. Makar, Seth G. Sanders, Lowell J. Taylor

Source: Industrial and Labor Relations Review, Vol. 56, No. 3 (Apr., 2003), pp. 449-469

Published by: Cornell University, School of Industrial \& Labor Relations

Stable URL: http://www.jstor.org/stable/3590918

Accessed: 09/07/2009 17:49

Your use of the JSTOR archive indicates your acceptance of JSTOR's Terms and Conditions of Use, available at http://www.jstor.org/page/info/about/policies/terms.jsp. JSTOR's Terms and Conditions of Use provides, in part, that unless you have obtained prior permission, you may not download an entire issue of a journal or multiple copies of articles, and you may use content in the JSTOR archive only for your personal, non-commercial use.

Please contact the publisher regarding any further use of this work. Publisher contact information may be obtained at http://www.jstor.org/action/showPublisher?publisherCode=cschool.

Each copy of any part of a JSTOR transmission must contain the same copyright notice that appears on the screen or printed page of such transmission.

JSTOR is a not-for-profit organization founded in 1995 to build trusted digital archives for scholarship. We work with the scholarly community to preserve their work and the materials they rely upon, and to build a common research platform that promotes the discovery and use of these resources. For more information about JSTOR, please contact support@jstor.org. 


\title{
THE EARNINGS EFFECTS OF SEXUAL ORIENTATION
}

\author{
DAN A. BLACK, HODA R. MAKAR, SETH G. SANDERS, and LOWELL J. TAYLOR*
}

This investigation of the effect of sexual orientation on earnings employs General Social Survey data from 1989-96. Depending largely on the definition of sexual orientation used, earnings are estimated as having been between $14 \%$ and $16 \%$ lower for gay men than for heterosexual men, and between $20 \%$ and $34 \%$ higher for lesbian women than for heterosexual women. This evidence, the authors suggest, is consistent with either of two complementary constructions: Gary Becker's argument that male/female earnings differentials are rooted in specialization within households and in optimal human capital accumulation decisions individuals make when they are young; and Claudia Goldin's observations about marriage-based gender discrimination, according to which the paternalistic "protection" of wives and mothers from the world of work has tended to overlook lesbians.

$\mathbf{T}$ he past decade has been marked by a significant amount of public policy debate and legislation regarding gay and lesbian Americans. For example, initiatives designed to prohibit discrimination or, conversely, to prohibit civil rights protection based on sexual orientation have been debated at virtually all levels of government. For the most part, public dis-

\footnotetext{
*Dan Black is Professor of Economics at Syracuse University, Hoda Makar contributed to this paper while she was completing an M.A. in Sociology at the University of Chicago, Seth Sanders is Associate Professor of Economics at the University of Maryland, and Lowell Taylor is Professor of Economics at the Heinz School, Carnegie Mellon University. The authors gratefully acknowledge research support from NICHD Grant HD3703-01 430. They thank participants at the 1999 Conference on the Economics of Sex Roles and the Family at the University of Texas at Austin for helpful comments on earlier drafts of this paper.

Programs used to generate key results are available from Professor Black, Center for Policy Research, 426 Eggers Hall, Syracuse University, Syracuse, NY 13244-1020.
}

course on these issues has not been informed or supported by empirical work that uses probability samples.

The problem for social scientists seeking to understand issues related to sexual orientation is that much of the research in the study of gays and lesbians is conducted using small "convenience samples." These samples are often drawn from readers of particular magazines or newspapers, or responses solicited from Internet sites or in gay bars. Often these samples do not include comparison groups of heterosexual individuals. ${ }^{1}$ The problem, of course, has been the absence of large systematic data sets that include information on sexual orientation.

\footnotetext{
${ }^{1}$ Blumstein and Schwartz's (1983) landmark work, American Couples, while not employing a random sample (the sample consisted of "volunteers" recruited in various ways), was based on data collected from comparable heterosexual and homosexual couples using the same instruments. It represented an important advance in the study of gays and lesbians.
} 
Until recently, there have been only two important exceptions. ${ }^{2}$ In their book The Social Organization of Sexuality (1994), Laumann, Gagnon, Michael, and Michaels dedicated a chapter to homosexuality. ${ }^{3}$ This chapter focused on the definition of homosexuality and the prevalence of gay, lesbian, and bisexual behavior in the United States. Although this research is by far the most useful and extensive work of its type, any inferences drawn about gays and lesbians must be based on very small samples. Only 24 women identified themselves as lesbians and only 39 men identified themselves as gay in a sample of 3,432 American men and women. In spite of relatively small samples, however, the authors were able to show how varying definitions of homosexuality greatly affect the measured incidence rates. ${ }^{4}$

The second exception is Badgett (1995). Using pooled data from the 1989-91 General Social Survey (GSS), Badgett investigated the relationship between sexual orientation and earnings. In her key analyses,

\footnotetext{
${ }^{2}$ After our paper was written and accepted for publication, at least two additional papers appeared on this topic: Berg and Lien (2002), which uses GSS data, and Allegretto and Arthur (2001), which examines same-sex partners in the U.S. Census.

${ }^{3}$ This work originated the National Health and Social Live Survey (NHSLS), a new survey on sexual behavior in America.

${ }^{4}$ Laumann et al. (1994) found that while the incidence rate of homosexual desire was $7.7 \%$ for men and $7.5 \%$ for women, the rate at which men identified themselves as gay was $2.8 \%$ and the rate at which women identified themselves as lesbian was $1.4 \%$. These latter rates were similar to the rates at which men and women had exclusively same-sex sex $(3.0 \%$ and $1.6 \%)$. These findings are important for two reasons. First, they highlight the ambiguity in defining homosexuality. This underscores the necessity for caution when researchers seek to estimate the relationship between homosexuality and other characteristics such as earnings. Second, given the widespread belief, supported by Kinsey's pioneering research (see Kinsey, Pomeroy, Martin, and Gebhard 1948 ), that " $10 \%$ of men are more or less exclusively homosexual," the results of Laumann et al. demonstrate the importance of sampling from a known population.
}

she defined lesbians, gay men, and bisexuals as individuals having more same-sex sexual partners than opposite-sex sexual partners since age 18. Using this definition, and controlling for a variety of characteristics, she found that gay men earned $28 \%$ less than heterosexual men and lesbians earned $35 \%$ less than heterosexual women (although only the result for men was statistically significant). As in Laumann et al., the gay and lesbian samples were very small.

Badgett's paper is the point of departure for our work. Her results are striking for two reasons. First, the point estimates are very large, especially given the expansive definition of sexual orientation Badgett used. Laumann et al. found that having had sex exclusively with members of the same sex within the past year or within the past five years is much more highly correlated with self-identified homosexuality than are measures based on the number of same-sex sexual partners since age 18 . It is likely that many people defined as homosexual using "partners since age 18" definitions are not currently homosexual. In fact, Badgett found that over $40 \%$ of the "gay" men in her sample were married. ${ }^{5}$ Indeed, some of the men and women who are classified as homosexual are likely not currently behaviorally homosexual and would neither identify themselves nor be identified by potential employers as gay or lesbian. Presumably, individuals who are openly homosexual would face the most discrimination. If this is true, then the negative effects Badgett found, large as they are, may actually understate the effect of sexual orientation on earnings among individuals currently openly lesbian or gay.

Second, the finding that lesbians earn less than other women is striking on theo-

\footnotetext{
${ }^{5}$ As a comparison, $67 \%$ of heterosexual men in her sample are currently married. One possibility is that many men are "closet gays." To the extent that this is true, it is likely that employers do not know of their sexual orientation and thus cannot discriminate against them on this basis.
} 
retical grounds. Some of the earnings differences between gay and heterosexual men may result from heterosexual men (particularly married men) specializing more intensely than gay men in market production. For example, because a married man is more likely than a gay man to have a stayat-home partner and children, he may also place a higher priority on income, which in turn can affect such decisions as human capital accumulation, and willingness to work longer hours or accept a job that is more stressful. This specialization argument, however, should act to raise, not lower, lesbians' earnings.

In Becker's model of the family (Becker 1981), differences in market earnings of men and women are rooted in specialization within households and in optimal human capital accumulation decisions these individuals make when they are young. In this framework, women who are likely to specialize in home production will rationally choose to limit their accumulation of market skills, resulting in earnings lower than men's. At least some lesbian women, however, will make human capital accumulation decisions based on an understanding that they are unlikely to marry into traditional households. This would tend to increase, rather than lower, lesbians' market-oriented human capital relative to heterosexual women's. Some of this human capital accumulation would be unobservable, so in the absence of other effects in the market (for example, discrimination), this argument would lead us to expect lesbian women to earn more, on average, than other women with similar observed individual characteristics. ${ }^{6}$

\footnotetext{
${ }^{6}$ In the 1990 PUMS of the U.S. Census, women in same-sex partnerships earn more than comparable women in opposite-sex partnerships (both married and unmarried). See Klawitter (1997) and Black et al. (2000). As the Census identifies only partnered lesbians, it is obviously not a probability sample of all lesbian women. It would be surprising if partnered lesbian women, however, earned more than their heterosexual counterparts while at the same time single lesbian women earned less than their heterosexual counterparts.
}

By using larger samples, we may be able to validate Badgett's tentative finding of a large negative earnings effect for lesbian women. This finding would seem to provide strong evidence against the household specialization explanation for earnings differences by sexual orientation. It would instead be consistent with a market discrimination explanation in which gay men and lesbian women alike face poorer labor market prospects than their comparable heterosexual counterparts.

The systematic study of gay and lesbian individuals is valuable for both its policy relevance and its potential to inform social scientists about the functioning of labor markets. Until recently, there were no social science survey data drawn using careful probability sampling that contained sufficiently large subsamples of gay and lesbian individuals for separate analysis. By using the combined 1989-96 GSS surveys, the next section of this paper re-examines the earlier results of Badgett (1995) with a sample large enough to gain considerable additional precision.

Our sample is also large enough to allow exploration of several meaningfully distinct definitions of sexual orientation. As Lauman et al. stressed, what it means to be gay or lesbian is subject to considerable interpretation; no single set of criteria for defining sexual orientation is universally accepted. Therefore, classifying individuals by sexual orientation is subject to a great deal more ambiguity than classifying individuals by race, gender, or other minority status. Below, we explore the sensitivity of our results to varying definitions of sexual orientation. We also examine the issue of measurement error in constructing an individual's sexual orientation-an issue that has not been widely appreciated in the literature.

\section{Replication of Badgett's Findings}

The starting point for this section is a replication of Badgett's key regressions using the data available at the time of her study, the 1989-91 GSS data, and the exact definition of sexual orientation she em- 
ployed. Since succeeding waves of the GSS are now available, we repeat the analysis on all years of the GSS currently available1989 to $1991,1993,1994$, and $1996 .^{7}$ This analysis is intended to set a baseline for analyses that use alternative definitions of sexual orientation and work that seeks to limit error in classifying sexual orientation.

Following Badgett's analysis, we restrict our attention to full-time workers for whom we have complete information on earnings as well as basic correlates, including age, race, marital status, education, and geographic location. One of the challenges of using the GSS data is that the earnings data are categorical. In our work we use "interval regressions" that explicitly account for the interval nature of the data. ${ }^{8}$

${ }^{7}$ The size of the GSS sample was doubled since 1993. The use of the additional years of data approximately triples the size of the sample used for analysis.

${ }^{8}$ In estimating her earnings equations, Badgett replaced the income category with the conditional median of the category, which she estimated from the Current Population Survey (CPS). Since she was unable to identify sexual orientation from the CPS, she assumed that the median of homosexuals' earnings is the same as the median of heterosexuals' earnings conditional on gender and on being in a given income category. This will, in general, result in biased parameter estimates, because these conditional medians will not be the same for heterosexuals and homosexuals unless the distributions of earnings are the same.

An alternative strategy, which we adopt, is to assume normality of the error term, and estimate the model explicitly accounting for the interval nature of the data. Suppose the $\mathrm{t}^{\text {th }}$ observation lies in the interval $\left[c_{t 0}, c_{t 1}\right]$ and suppose that the logarithm of income, $y_{t}$, is normally distributed. The likelihood function is simply

$$
\mathrm{L}=\prod_{i=1}^{n} \int_{c_{i 0}}^{c_{i 1}} f\left(s_{i}-X_{i} \boldsymbol{\beta}\right) d s,
$$

where $f(\cdot)$ is the normal pdf, $X_{i}$ is a vector of covariates, and $\beta$ is a vector of parameters to be estimated. We obtain parameter estimates by maximizing this equation. We account explicitly for changes in the real value of the end points and changes in the categories over time. (We follow Badgett and deflate using the CPI.)

Having said all this, we note that estimates drawn using this "interval regression" procedure are very similar to the OLS estimates.
Table 1 shows the mean values and sample sizes for two samples from the GSS. Columns (1) and (3) list characteristics of the 1989-91 GSS, the sample used by Badgett. ${ }^{9}$ Columns (2) and (4) present the extended sample, constructed by the same method, on all available years of the GSS in which respondents were asked about sexual orientation. For women (Panel A), this increases the sample size of lesbian/bisexual women from 34 to 101 and of heterosexual women from 709 to 2,145. (Following Badgett, our most inclusive definition, used in the presentation of summary statistics, defines an individual as gay/bisexual or lesbian/bisexual if he or she has had a same sex sexual partner since age 18.) For men (Panel B), this increases the sample size of gay/bisexual men from 47 to 114 and of heterosexual men from 904 to 2,519 .

It is worth noting that while the data from 1989-91 suggest that heterosexual women earned substantially more than lesbian/bisexual women $(\$ 18,341$ versus $\$ 15,056)$, the data on all years suggest that lesbian/bisexual women may actually have earned more than heterosexual women $(\$ 21,248$ versus $\$ 19,514)$. The mean earnings of gay/bisexual men were lower than those of heterosexual men. This finding is robust across sample years. Furthermore, gays and lesbians clearly differed from their heterosexual counterparts in many ways. While gays and lesbians had levels of education similar to those of their heterosexual counterparts, they were half as likely to be married, they were more likely to live in the West and Northeast, and they were more likely to live in large cities. Following Badgett, we use regression analysis to control for these background differences.

${ }^{9}$ The 1989-91 subsample of gay and lesbian individuals presented here is identical to Badgett's original sample. Our sample contains 11 additional heterosexual women and 3 additional heterosexual men. However, neither the sample statistics nor the regression coefficients presented here for the 1989-91 sample differ from those in Badgett's original analysis in any meaningful way. 
Tables 2 and 3 present for men and women, respectively, the regression coefficients from a regression of the logarithm of earnings (1989 dollars) on the background characteristics presented in Table 1 . In each case, we use Badgett's specification and follow the definition of lesbian/gay/ bisexual she used in her regression analyses. These regressions all include education, race, experience, experience squared, marital status, living in a large city, and region of residence. Following Badgett, in the women's equation we also include the interaction of experience and the lesbian or bisexual variable, but this is not done in the men's equation. As Badgett did, we use the Mincerian definition of potential experience (age minus years of schooling minus 6 ), because an actual measure of experience is not available in the GSS.

In these regressions an individual is defined as lesbian/gay/bisexual if he or she had had at least as many same-sex sexual partners since age 18 as opposite-sex sexual partners. In each of these tables, column (1) lists estimated coefficients for the 1989-91 sample, and column (2) lists estimated coefficients for these same regressions with the larger sample (GSS 1989-96). Regression models for both time periods are estimated using interval regression. ${ }^{10}$

We find that the results for men are not greatly affected by our having expanded the sample. The estimated earnings effect of being a gay or bisexual man changes from -0.27 using the 1989-91 sample to about -0.21 with the larger sample. The results for men remain statistically and economically meaningful.

The effects of sexual orientation on earnings for lesbians are not as robust in response to changes in the sample, and are in any event ambiguous. The point estimate on the lesbian or bisexual status variable drops from -0.35 to -0.22 and remains

\footnotetext{
${ }^{10}$ Badgett used an alternative approximation strategy to tackle the categorical recording of earnings in the GSS. All coefficient estimates for the 1989-91 period, however, are nearly identical to the results reported in Badgett's original work.
}

statistically insignificant. One might argue that an approximately $22 \%$ difference in earnings between lesbians/bisexuals and other women is still economically important. The interaction term between lesbian or bisexual status and potential labor market experience, however, is positive (and indeed is statistically significant at the 0.10 level). Evaluated at the mean level of potential labor market experience, lesbian/ bisexual status raises earnings by more than $6 \%$.

The effects of other covariates on earnings are as expected in sign. In addition, in the regressions that use the extended GSS sample, the effects of the other covariates are qualitatively similar to estimates from Badgett's 1989-91 sample.

\section{Definitions of \\ Homosexuality and Inferences about Sexual Orientation and Earnings}

Laumann et al. (1994) and Badgett (1995) both discussed the difficulty of defining homosexuality. Laumann et al. discussed three distinct concepts of homosexuality and estimated the incidence of homosexuality under each definition. First, homosexuality can be defined in terms of attraction to members of the same sex or desire to have sex with a member of the same sex. Using a question in the NHSLS that asks, "In general, are you sexually attracted to only men, mostly men, both men and women, mostly women, or only women?" Laumann et al. found that $6.2 \%$ of men and $4.4 \%$ of women were attracted to some degree to members of their own sex. Using the question, "On a scale of 1 to 4 , where 1 is very appealing and 4 is not at all appealing, how would you rate ... having sex with someone of the same sex?" they found that $4.5 \%$ of men and $5.6 \%$ of women found same-sex sex either "somewhat appealing" or "very appealing." They found that $7.7 \%$ of men and $7.5 \%$ of women were homosexual if homosexuality was defined as having either a desire for same-sex sex or an attraction to members of the same sex.

These rates stand in sharp contrast to the incidence rate of homosexuality defined by 
Table 1. Variable Means for Full-Time Workers:

Badgett's 1989-91 GSS Sample and the 1989-96 GSS Sample.

Panel A: Women

\begin{tabular}{|c|c|c|c|c|}
\hline \multirow[b]{2}{*}{ Variables } & \multicolumn{2}{|c|}{ Lesbian/Bisexual Women } & \multicolumn{2}{|c|}{ Heterosexual Women } \\
\hline & $\begin{array}{c}\text { 1989-91 } \\
\text { GSS Sample } \\
\text { (1) }\end{array}$ & $\begin{array}{c}\text { 1989-1996 } \\
\text { GSS Sample } \\
\text { (2) }\end{array}$ & $\begin{array}{c}\text { 1989-91 } \\
\text { GSS Sample } \\
\text { (3) }\end{array}$ & $\begin{array}{c}\text { 1989-1996 } \\
\text { GSS Sample } \\
\text { (4) }\end{array}$ \\
\hline Annual Earnings ${ }^{\mathrm{a}}$ & $\$ 15,056$ & $\$ 21,248$ & $\$ 18,246$ & $\$ 19,514$ \\
\hline$\%$ with $\$ 0-\$ 9,999$ & 29.4 & 16.8 & 21.7 & 15.8 \\
\hline$\%$ with $\$ 10,000-\$ 19,999$ & 35.3 & 29.7 & 36.1 & 32.1 \\
\hline$\%$ with $\$ 20,000-\$ 29,999$ & 29.4 & 25.7 & 25.5 & 27.4 \\
\hline$\%$ with $\$ 30,000-\$ 39,999$ & 5.9 & 10.9 & 11.8 & 14.2 \\
\hline$\%$ with $\$ 40,000+$ & 0.0 & 16.8 & 4.8 & 10.5 \\
\hline Education & 13.6 & 14.3 & 13.6 & 13.9 \\
\hline Age & 34.0 & 36.4 & 39.5 & 39.7 \\
\hline Potential Experience & 15.4 & 17.1 & 20.8 & 20.8 \\
\hline$\%$ White & 79.4 & 80.2 & 85.5 & 83.4 \\
\hline$\%$ Married & 23.5 & 24.8 & 51.0 & 49.2 \\
\hline$\%$ Large SMSA & 55.9 & 71.3 & 52.0 & 51.6 \\
\hline \multicolumn{5}{|l|}{ Region (\%) } \\
\hline Northeast & 17.7 & 17.8 & 20.2 & 18.1 \\
\hline Midwest & 23.5 & 16.8 & 26.8 & 25.4 \\
\hline West & 17.7 & 26.7 & 19.6 & 22.0 \\
\hline South & 41.2 & 38.6 & 33.4 & 34.6 \\
\hline Observations & 34 & 101 & 709 & 2,145 \\
\hline
\end{tabular}

Panel B: Men

\begin{tabular}{|c|c|c|c|c|}
\hline \multirow[b]{2}{*}{ Variables } & \multicolumn{2}{|c|}{ Gay/Bisexual Men } & \multicolumn{2}{|c|}{ Heterosexual Men } \\
\hline & $\begin{array}{c}\text { 1989-91 } \\
\text { GSS Sample } \\
\text { (1) }\end{array}$ & $\begin{array}{c}1989-1996 \\
\text { GSS Sample } \\
\text { (2) }\end{array}$ & $\begin{array}{c}\text { 1989-91 } \\
\text { GSS Sample } \\
\text { (3) }\end{array}$ & $\begin{array}{c}\text { 1989-1996 } \\
\text { GSS Sample } \\
\text { (4) }\end{array}$ \\
\hline Annual Earning ${ }^{\mathrm{a}}$ & $\$ 26,321$ & $\$ 25,278$ & $\$ 28,279$ & $\$ 28,642$ \\
\hline$\%$ with $\$ 0-\$ 9,999$ & 10.6 & 7.9 & 9.0 & 7.6 \\
\hline$\%$ with $\$ 10,000-\$ 19,999$ & 29.8 & 25.4 & 22.5 & 18.1 \\
\hline$\%$ with $\$ 20,000-\$ 29,999$ & 21.3 & 26.3 & 26.1 & 24.5 \\
\hline$\%$ with $\$ 30,000-\$ 39,999$ & 17.0 & 16.7 & 19.4 & 20.3 \\
\hline$\%$ with $\$ 40,000+$ & 21.3 & 23.7 & 23.1 & 29.5 \\
\hline Education & 13.6 & 14.3 & 13.6 & 13.9 \\
\hline Age & 41.3 & 39.9 & 39.1 & 39.6 \\
\hline Potential Experience & 22.6 & 20.6 & 20.4 & 20.7 \\
\hline$\%$ White & 89.4 & 82.5 & 90.7 & 87.9 \\
\hline$\%$ Married & 40.4 & 30.7 & 67.6 & 63.3 \\
\hline$\%$ Large SMSA & 55.3 & 71.3 & 45.9 & 51.6 \\
\hline \multicolumn{5}{|l|}{ Region (\%) } \\
\hline Northeast & 25.5 & 25.4 & 18.4 & 18.4 \\
\hline Midwest & 29.8 & 22.8 & 26.6 & 26.3 \\
\hline West & 12.8 & 24.6 & 19.6 & 20.4 \\
\hline South & 31.9 & 27.2 & 35.5 & 34.9 \\
\hline Observations & 47 & 114 & 904 & 2,519 \\
\hline
\end{tabular}

${ }^{\mathrm{a}} 1989$ dollars. 
Table 2. Earnings Regressions for Men.

\begin{tabular}{|c|c|c|}
\hline Variable & $\begin{array}{c}\text { 1989-91 } \\
\text { GSS Data } \\
\quad(1)\end{array}$ & $\begin{array}{c}\text { 1989-96 } \\
\text { GSS Data } \\
\text { (2) }\end{array}$ \\
\hline Constant & $\begin{array}{r}7.88 \\
(58.3)\end{array}$ & $\begin{array}{r}7.74 \\
(92.6)\end{array}$ \\
\hline Gay or Bisexual ${ }^{\mathrm{a}}$ & $\begin{array}{c}-0.27 \\
(-2.24)\end{array}$ & $\begin{array}{c}-0.21 \\
(-2.79)\end{array}$ \\
\hline Education & $\begin{array}{r}0.10 \\
(12.8)\end{array}$ & $\begin{array}{r}0.10 \\
(21.2)\end{array}$ \\
\hline Currently Married & $\begin{array}{c}0.29 \\
(6.21)\end{array}$ & $\begin{array}{c}0.23 \\
(8.59)\end{array}$ \\
\hline White & $\begin{array}{c}0.07 \\
(0.89)\end{array}$ & $\begin{array}{c}0.07 \\
(1.83)\end{array}$ \\
\hline Potential Experience & $\begin{array}{c}0.04 \\
(6.07)\end{array}$ & $\begin{array}{r}0.06 \\
(14.5)\end{array}$ \\
\hline Experience Squared & $\begin{array}{l}-0.0005 \\
(-4.04)\end{array}$ & $\begin{array}{l}-0.0008 \\
(-10.2)\end{array}$ \\
\hline $\begin{array}{l}\text { Experience } * \text { Gay } \\
\text { or Bisexual }\end{array}$ & - & - \\
\hline Big SMSA & $\begin{array}{c}0.20 \\
(4.53)\end{array}$ & $\begin{array}{c}0.17 \\
(6.68)\end{array}$ \\
\hline Northeast & $\begin{array}{c}0.18 \\
(3.06)\end{array}$ & $\begin{array}{c}0.15 \\
(4.10)\end{array}$ \\
\hline Midwest & $\begin{array}{c}0.21 \\
(3.90)\end{array}$ & $\begin{array}{c}0.11 \\
(3.37)\end{array}$ \\
\hline West & $\begin{array}{c}0.12 \\
(1.89)\end{array}$ & $\begin{array}{c}0.02 \\
(0.63)\end{array}$ \\
\hline $\begin{array}{l}\text { Total Observations } \\
\text { Number of Gays and }\end{array}$ & 951 & 2,633 \\
\hline Bisexuals & 29 & 77 \\
\hline
\end{tabular}

${ }^{\mathrm{a}} \mathrm{Gay} / \mathrm{bisexual}$ is defined as having at least as many same-sex sexual partners as opposite-sex sexual partners. T-statistics are in parentheses. The dependent variable is the log of annual earnings. All regression analyses use the interval regression technique.

self-identification. Using the response to the question, "Do you think of yourself as heterosexual, homosexual, bisexual, or something else?" they found that a much smaller fraction of men $(2.8 \%)$ and women (1.4\%) considered themselves homosexual.

Finally, Laumann et al. investigated definitions of homosexuality based on the respondents' sexual experience. They labeled this homosexuality based on sexual behavior, and considered several forms of sexual behavior that might lead to the classification of a respondent as homosexual.
Table 3. Earnings Regressions for Women.

\begin{tabular}{|c|c|c|}
\hline Variable & $\begin{array}{l}\text { 1989-91 } \\
\text { GSS Data } \\
\quad(1)\end{array}$ & $\begin{array}{c}\text { 1989-96 } \\
\text { GSS Data } \\
\text { (2) }\end{array}$ \\
\hline Constant & $\begin{array}{r}7.38 \\
(38.2)\end{array}$ & $\begin{array}{r}7.38 \\
(72.1)\end{array}$ \\
\hline Lesbian or Bisexual $^{\mathrm{a}}$ & $\begin{array}{l}-0.35 \\
(-1.12)\end{array}$ & $\begin{array}{c}-0.22 \\
(-1.21)\end{array}$ \\
\hline Education & $\begin{array}{r}0.12 \\
(10.7)\end{array}$ & $\begin{array}{r}0.12 \\
(20.6)\end{array}$ \\
\hline Currently Married & $\begin{array}{c}-0.09 \\
(-1.69)\end{array}$ & $\begin{array}{c}-0.03 \\
(-1.17)\end{array}$ \\
\hline White & $\begin{array}{c}0.10 \\
(1.25)\end{array}$ & $\begin{array}{c}0.07 \\
(1.77)\end{array}$ \\
\hline Potential Experience & $\begin{array}{c}0.04 \\
(5.40)\end{array}$ & $\begin{array}{r}0.05 \\
(10.5)\end{array}$ \\
\hline Experience Squared & $\begin{array}{l}-0.0007 \\
(-4.31)\end{array}$ & $\begin{array}{l}-0.0007 \\
(-7.79)\end{array}$ \\
\hline Experience $* \mathrm{~L} / \mathrm{G} / \mathrm{B}$ & $\begin{array}{c}0.01 \\
(0.77)\end{array}$ & $\begin{array}{c}0.01 \\
(1.83)\end{array}$ \\
\hline Big SMSA & $\begin{array}{c}0.27 \\
(4.66)\end{array}$ & $\begin{array}{c}0.16 \\
(5.21)\end{array}$ \\
\hline Northeast & $\begin{array}{c}0.09 \\
(1.22)\end{array}$ & $\begin{array}{c}0.16 \\
(3.83)\end{array}$ \\
\hline Midwest & $\begin{array}{l}0.0017 \\
(0.03)\end{array}$ & $\begin{array}{l}-0.0004 \\
(-0.01)\end{array}$ \\
\hline West & $\begin{array}{c}-0.07 \\
(-0.89)\end{array}$ & $\begin{array}{c}0.02 \\
(0.53)\end{array}$ \\
\hline $\begin{array}{l}\text { Total Observations } \\
\text { Number of Lesbians } \\
\text { and Bisexuals }\end{array}$ & 743 & 2,246 \\
\hline
\end{tabular}

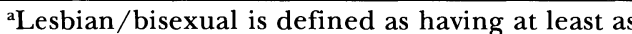
many same-sex sexual partners as opposite-sex sexual partners. T-statistics are in parentheses. The dependent variable is the $\log$ of annual earnings. All regression analyses use the interval regression technique.

Broadly put, homosexual behavior can be recent behavior (over the past year or past five years) or past behavior (since age 18 or since puberty). These measures are of particular interest to us as they are the only measures that are available in both the GSS and NHSLS and hence the only measures that will give us sample sizes large enough to investigate the effects of sexual orientation on earnings. ${ }^{11}$

\footnotetext{
${ }^{11}$ To determine recent sexual behavior, the GSS specifically asks both men and women, "Have your sex
} 
Four measures of homosexual/bisexual behavior can be defined in the GSS. Badgett (1995) presented analyses based on two of these definitions. Her first definition of homosexuality/bisexuality was having had a same-sex partner since age 18 . Her second definition was having had more samesex than opposite-sex partners since age 18. Below, we present analysis based on two measures of more recent sexual behavior: (1) having had exclusively same-sex sex or having had sex with both men and women over the past year, and (2) having had exclusively same-sex sex or sex with both men and women over the past five years.

Though different, all the above measures are legitimate measures of homosexuality. It is not clear, however, that they are all equally valuable in addressing the relationship between sexual orientation and earnings. Below we outline arguments suggesting that earnings differences due to sexual orientation are most likely to be found among men and women who are engaged at present in a "gay or lesbian lifestyle." In short, it is possible that because of the dynamic nature of sexuality, including sexual experimentation early in one's adult life, definitions of homosexuality that are based on sexual behavior reflecting the distant past do not isolate the group of gays and lesbians who are most affected by their sexual orientation. In fact, many men and women who are classified as homosexual based on the number of same-sex partners since age 18 may at present lead heterosexual lives and be indistinguishable from heterosexuals who have never had a same-sex experience.

Before documenting the fluidity of sexuality, we turn briefly to two familiar poten-

partners in the last 12 months been ... exclusively male, both male and female, exclusively female?" Starting in 1991, the GSS also asked a parallel question referring to the past 5 years. More distant sexual behavior is assessed based on responses to two questions: "Now thinking about the time since your 18th birthday (including the past 12 months) how many female partners have you had sex with?" and a parallel question concerning male partners. tially relevant economic arguments-the basic economic story of labor market discrimination and the economic model of specialization within families.

In his well-known book The Economics of Discrimination (1971), Becker posited a simple model of how "taste for discrimination" by employers, employees, or consumers can affect the earnings of a minority group. Consider the version of the model in which an employer has a taste for discrimination such that for every dollar in wages that he pays a minority worker he suffers a monetized disutility of $d$ dollars. The employer is willing to hire minorities, but only if he can pay them $w(1-d)$ dollars, while paying non-minority workers $w$ dollars. Becker pointed out that if minority and non-minority workers are equally productive, non-discriminating employers $(d=0)$ will bid minority workers away from discriminating employers. There can be many discriminating employers, but if there are enough non-discriminating employers, minorities and non-minorities will have equal earnings in equilibrium. They will, however, work for different firms. Segregation in this setting is evidence of discrimination.

Earnings differences occur if the number of job-seekers in the minority group exceeds the number of jobs offered by nondiscriminating employers, and hence some members of the minority group take jobs with discriminating employers. When this occurs, it is not only the minority members working at discriminating employers who receive lower wages. Profit-maximizing nondiscriminating employers (who would be willing to pay members of the minority workers equal wages) in equilibrium also pay their minority workers lower wages. Analogous stories can be told for discrimination that arises from preferences of coworkers or customers.

This basic story of market discrimination suggests that there is potential for sexual orientation to lower earnings through the discriminatory practices of employers. Whether this occurs depends crucially on two factors. The first factor is the size of the gay and lesbian population relative to the 
number of jobs offered by non-discriminatory employers. While the gay and lesbian populations are small relative to the populations of other minority groups, the degree of discrimination against gays and lesbians (and the number of discriminatory employers) may be larger than for other minority groups. For example, in the GSS data $83 \%$ of men and $80 \%$ of women responded that same-sex sexual relations are "always wrong" or "usually wrong." Historical accounts and current literature are replete with examples of severe anti-gay attitudes and discriminatory practices.

The second important factor influencing the potential for sexual orientation to lower earnings through employer discrimination is the employers' ability to distinguish gays and lesbians from other men and women. While there are several definitions of homosexuality, some are not relevant to explaining the relationship between homosexuality and labor market earnings if we believe that this relationship operates through employers' taste for discrimination. Even if employers wish to discriminate against employees who have homosexual desire, fantasies, or past homosexual experience, they have few ways to judge these aspects of individuals' lives. Because gays and lesbians can often "pass" if they choose, it is likely that employers frequently become aware of an employee's sexual orientation when the employee chooses not to "pass." This may include being open about sexuality at work or leading an open homosexual lifestyle outside of work.

We do not observe the "openness" of gays or lesbians in our survey data, but it seems likely that current homosexual behavior is more reflective of current potentially observable "openness" than is past homosexual behavior. In this case, if earnings differences by sexual orientation are due to employer discrimination, we would expect these differences to be largest for individuals who are currently gay or lesbian. To the extent that employers only imperfectly observe the sexual orientation of their employees, however, any evidence of discrimination we do find represents an understatement of the extent of discrimination against gays and lesbians.

A different potentially relevant economic model for understanding the relationship between sexual orientation and earnings comes from the theory of specialization within the household as presented by Becker (1981) in A Treatise on the Family. Becker argued that differences between men and women in market earnings are rooted in specialization within households and in optimal human capital accumulation decisions individuals make when they are young. Even in the United States in the early twentyfirst century, many women believe that they are likely to specialize in home production and respond rationally to that expectation by limiting their accumulation of market skills. This in turn results in earnings below those of men. The predictions from a simple extension to the Becker model are clear. Lesbian women who realize early in life that they will not marry will invest more heavily in market-oriented human capital than heterosexual women do. They will subsequently be observed to earn more than other women. ${ }^{12}$ If some market-oriented human capital is unobservable, then in a regression of earnings on personal characteristics and sexual orientation, one would expect a positive coefficient on the $\mathrm{L} / \mathrm{B} / \mathrm{G}$ variable for women.

The argument for men is somewhat different. Single men and men in gay relationships are predicted to earn less than married men to the extent that they specialize less intensely in market production than do married heterosexual men. If heterosexual men make human capital investments under the expectation that they will marry, and instead remain single, these

\footnotetext{
${ }^{12}$ Lesbian women who marry and subsequently divorce and enter in to a same-sex relationship should be observed to earn less than never-married lesbian women. In a working paper version of Black, Gates, Sanders, and Taylor (2000), the authors found evidence of this pattern of earnings in the large sample of female same-sex partners in the 1990 PUMS of the U.S. Census.
} 
men will have "over-invested" in human capital, and may earn more than gay men who from a younger age understood that it was unlikely that they would form traditional households. More generally, married men (especially those with a stay-athome spouse or children) will make a series of income-related decisions that may differ from those of single or gay men, including willingness to work long hours, accept stressful work conditions, or pursue a promotion that entails moving to another city.

In the economic story of specialization just outlined, expectations of marriage and acceptance of traditional gender roles drive the relationship between sexual orientation and earnings. In this theory, forms of homosexual activity that do not influence an individual's probability of marrying and accepting the traditional gender roles are irrelevant to the relationship between sexual orientation and earnings. For example, an individual may experience same-sex attraction but choose not to act on this attraction. Similarly, early sexual experiences (and experimentation) that did not change other aspects of a person's life related to specialization (such as how much or what type of human capital to accumulate, or what occupation to enter) are also irrelevant to current earnings.

The major point of our discussion is that if either discrimination theory or the household specialization/human capital accumulation theory is a mechanism by which sexual orientation affects earnings, the appropriate measure of sexual orientation is one that reflects a commitment to a "gay or lesbian lifestyle." By this we mean a lifestyle that differs from traditional family patterns, including marriage, or in which employers, co-workers, and customers might discover the person's homosexual orientation. Available data do not allow us to assess the extent to which individuals fit this definition. However, it seems likely that being currently engaged in same-sex sexual activity is more reflective of this construct than measures of homosexuality based on distant past behavior.

With this in mind, we turn to the GSS and NHSLS data. Table 4 presents the number and incidence rates of gays, lesbians, and bisexuals by various definitions in the combined years of the GSS (1989-91, 1993, 1994, and 1996) and in the NHSLS. The definition used to generate the results in row 1 is "having at least one same-sex sex partner since age 18"; in row 2, "having more same-sex sexual partners since age 18 than opposite-sex sex partners"; in row 3, "having exclusively same-sex sex over the past year"; and in row 4, "having had sex with both sexes over the previous year." For rows 5 and 6 , we use the same definitions as for rows 3 and 4 , but with a time frame of the past five years rather than the past year. Row 7 presents the results for self-identified gays or lesbians.

As we have noted, for the 1989-91 GSS data, Badgett used the definitions in row 1 and row 2 (which include 47 men and 34 women who were gay, lesbian, or bisexual). By combining seven years of the GSS, we achieve sample sizes that are large enough to permit estimation of earnings regressions with several different definitions of homosexuality. In particular, by the definitions "having had exclusively same-sex sex over the previous year" and "having had sex with both men and women over the previous year," a total of 172 men are gay (139) or bisexual (33), and a total of 117 women are lesbian (88) or bisexual (29) (rows 3 and 4 ). These definitions have the advantage of measuring current sexual behavior. Also, this question was asked in each year of the GSS and in the NHSLS.

The drawback to those definitions is that over a one-year period a substantial fraction of the population had not engaged in sexual activity at all, and their orientation thus cannot be identified. ${ }^{13}$ A fourth definition for sexual orientation extends the time frame to the previous five years (rows 5 and 6). Unfortunately, this question is asked in only 4 of the 7 GSS years (it is also asked in the NHSLS). Using this definition, we find 115 gay men and 78 lesbian

\footnotetext{
${ }^{13}$ This is approximately $10 \%$ of men and $13 \%$ of women.
} 
Table 4. Sample Sizes of Gays and Lesbians in the GSS and NHSLS for Various Definitions of Sexual Orientation.

\begin{tabular}{|c|c|c|c|c|}
\hline Definition & Lesbians & Bisexual Women & Gays & Bisexual Men \\
\hline $\begin{array}{l}\text { 1. At Least One Same-Sex Sex } \\
\text { Partner Since Age } 18^{\mathrm{a}}\end{array}$ & \multicolumn{2}{|c|}{$260(3.6 \%)$} & \multicolumn{2}{|c|}{$260(4.7 \%)$} \\
\hline $\begin{array}{l}\text { 2. More Same-Sex Than Opposite- } \\
\text { Sex Sex Partners Since Age } 18\end{array}$ & \multicolumn{2}{|c|}{$123(1.8 \%)$} & \multicolumn{2}{|c|}{$164(3.1 \%)$} \\
\hline $\begin{array}{l}\text { 3. Exclusively Same-Sex Sex } \\
\text { Partners over the Last Year }{ }^{\mathrm{b}}\end{array}$ & $88(1.4 \%)$ & 一 & $139(2.5 \%)$ & 一 \\
\hline $\begin{array}{l}\text { 4. Sex with Men and Women in } \\
\text { Last Year }\end{array}$ & - & $29(0.5 \%)$ & - & $33(0.6 \%)$ \\
\hline $\begin{array}{l}\text { 5. Exclusively Same-Sex Sex } \\
\text { Partners over the Past Five Years }{ }^{\mathrm{b}, \mathrm{c}}\end{array}$ & $78(1.5 \%)$ & - & $115(2.6 \%)$ & 一 \\
\hline $\begin{array}{l}\text { 6. Sex with Men and Women in the } \\
\text { Past Five Years }\end{array}$ & 一 & $66(1.2 \%)$ & - & $72(1.6 \%)$ \\
\hline 7. Self-Identified Gay or Lesbian ${ }^{d}$ & $12(0.6 \%)$ & $10(0.5 \%)$ & $27(1.8 \%)$ & $11(0.5 \%)$ \\
\hline
\end{tabular}

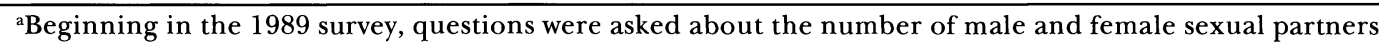
of the respondent since age 18 .

${ }^{b}$ Categories included exclusively same-sex sex, exclusively opposite-sex sex, sex with both men and women, and no sex during the relevant time period. More individuals may have had exclusively same-sex sex over the past 5 years than over the past year, because fewer individuals are in the "no sex" category over the past 5 years than in the 1-year time period.

'Asked in the GSS in 1991-96 only.

dAsked only in the NHSLS.

women. We also find 72 men and 66 women who had sex over the previous 5 years with both men and women.

Finally, we present the number of respondents in the NHSLS that self-identified as being gay, lesbian, or bisexual (row 5 ). Of the nearly 3,500 respondents, 27 men self-identified as gay, 12 women selfidentified as lesbian, and an additional 11 men and 10 women self-identified as bisexual.

It is not clear which of these definitions best captures our notion of leading a gay or lesbian lifestyle. It may be that self-identification is closest to the construct we are trying to capture. These men and women reported openly to a survey taker that they considered themselves gay or lesbian. At a minimum, these respondents had a willingness to vocalize their sexual orientation to the survey taker. This may indicate a certain degree of openness by the respondent, an openness that may be noticed by others, including employers. Unfortunately, this question was only asked in the NHSLS, and thus the size of the group is too small for our purposes. Therefore, we ask which alternative definition seems to best capture our common notion of leading a gay or lesbian lifestyle.

Table 5 presents some evidence that different definitions of sexual orientation create conceptually distinct groups. This table presents sexual behavior over the previous year for respondents who had had a samesex sex partner over different periods of their lives. Several features of the data stand out. First, the strength of the link between engaging exclusively in homosexual sex in the current year and having had a same-sex partner previously depends very much on how long ago the same-sex partnership occurred. For example, only $36 \%$ of men and $29 \%$ of women who had had a same-sex partner some time since age 18 were currently engaged in exclusively homosexual sex. Perhaps more telling, $38 \%$ of men and nearly $50 \%$ of women who had had a same-sex sex partner since age 18 were currently engaged in exclusively hetero- 
Table 5. Recent Sexual Behavior of Individuals with at Least One Same-Sex Sex Partner, GSS and NHSLS Data, 1989-96.

\begin{tabular}{|c|c|c|c|c|c|c|}
\hline \multirow[b]{2}{*}{ Sex of Partner(s) } & \multicolumn{2}{|c|}{$\begin{array}{c}\text { Same-Sex Sex } \\
\text { Partner Last Year }\end{array}$} & \multicolumn{2}{|c|}{$\begin{array}{c}\text { Same-Sex Sex } \\
\text { Partner in Past } 5 \text { Years } \\
\end{array}$} & \multicolumn{2}{|c|}{$\begin{array}{c}\text { Same-Sex Sex } \\
\text { Partner Since Age } 18^{c}\end{array}$} \\
\hline & Men & Women & Men & Women & Men & Women \\
\hline No Partner Last Year & $0.0 \%$ & $0.0 \%$ & $9.4 \%$ & $7.3 \%$ & $17.3 \%$ & $12.7 \%$ \\
\hline $\begin{array}{l}\text { Opposite-Sex Partner(s) } \\
\text { Only Last Year }\end{array}$ & 0.0 & 0.0 & 20.0 & 23.9 & 38.4 & 49.6 \\
\hline $\begin{array}{l}\text { Both Male and Female } \\
\text { Partners Last Year }\end{array}$ & 19.2 & 24.8 & 11.7 & 16.7 & 8.2 & 8.7 \\
\hline $\begin{array}{l}\text { Same-Sex Sex Partners Only } \\
\text { Last Year }\end{array}$ & 80.8 & 75.2 & 58.9 & 52.2 & 36.1 & 29.0 \\
\hline $\begin{array}{l}\text { Total } \\
\text { Number of Observations }\end{array}$ & $\begin{array}{c}100.0 \\
172\end{array}$ & $\begin{array}{c}100.0 \\
117\end{array}$ & $\begin{array}{c}100.0 \\
180\end{array}$ & $\begin{array}{c}100.0 \\
138\end{array}$ & $\begin{array}{c}100.0 \\
255\end{array}$ & $\begin{array}{c}100.0 \\
252\end{array}$ \\
\hline
\end{tabular}

${ }^{a}$ Having either exclusively same-sex sex or sex with both men and women past year. There are 5 missing values of sex last year for men and 8 for women.

${ }^{b}$ Having either exclusively same-sex sex or sex with both men and women in the past five years. There are 5 missing values of sex last year for men and 8 for women.

${ }^{c}$ Having at least one same-sex sex partner since age 18.

sexual sex. These features of the sample would seem to rule out "having a same-sex partner since age 18 " as a useful concept for assessing a current gay or lesbian lifestyle. In contrast, $81 \%$ of men and $75 \%$ of women who had had same-sex sex over the year prior to the survey had had no sex with members of the opposite sex during that year. This may make this measure more useful for identifying individuals who fit the construct of having a current gay or lesbian lifestyle.

In sum, theoretical considerations and an exploration of our sample lead us to believe that in studying the relationship between earnings and sexual orientation, it is important to investigate definitions of sexual orientation that reflect current behavior and lifestyle. We thus return to our regressions to explore the robustness of findings using the alternative definitions we have outlined. In particular, the main variables of interest are our two definitions of sexual orientation based on recent sexual behavior. It should be clear that in constructing these variables we must be careful to distinguish between homosexuality, heterosexuality, bisexuality, and no sexual activity (since we find a substantial fraction of the population that is not sexually active) ${ }^{14}$

\section{The Relationship between Sexual Orientation and Earnings}

Our sample criteria are the same as those used by Badgett (1995). The analysis is limited to men and women who are working full-time or who are employed full-time but were not at work the week of the survey. We follow these restrictions for two reasons. First, they allow us to easily compare our results to Badgett's original work, as we only change the definition of sexual orientation while keeping her methodology intact. Second, detailed information on the number of hours worked is needed to compare the earnings of workers who are less than full-time. This information is avail-

\footnotetext{
${ }^{14}$ Separating out individuals who have had no sex might be reasonable if there are unobservable selection effects-individuals who find partners (married or same-sex) may also be more adept at finding good jobs. Daniel (1996) found that two-thirds of the marriage premium in men's wages is from selection.
} 
Table 6. Number of Observations of Full-Time Workers Using Differing Definitions of Sexual Orientation, GSS Data, 1989-96.

\begin{tabular}{|c|c|c|}
\hline Definition & Men & Women \\
\hline \multicolumn{3}{|l|}{ I. Partners Since Age 18} \\
\hline $\begin{array}{l}\text { 1. At least as many same-sex as opposite-sex partners } \\
\text { (Homosexual or Bisexual) } \\
\text { 2. Fewer same-sex than opposite-sex partners (Heterosexual) }\end{array}$ & $\begin{array}{r}77 \\
2,417\end{array}$ & $\begin{array}{r}53 \\
2,193\end{array}$ \\
\hline \multicolumn{3}{|l|}{ II. Sexual Behavior over Past Year } \\
\hline $\begin{array}{l}\text { 1. No sex last year } \\
\text { 2. Same-sex sex only last year (Homosexual) } \\
\text { 3. Same- and opposite-sex sex last year (Bisexual) } \\
\text { 4. Opposite-sex sex only last year (Heterosexual) }\end{array}$ & $\begin{array}{r}209 \\
50 \\
10 \\
2,285\end{array}$ & $\begin{array}{r}341 \\
38 \\
11 \\
1,803\end{array}$ \\
\hline \multicolumn{3}{|l|}{ III. Sexual Behavior over Past 5 Years } \\
\hline $\begin{array}{l}\text { 1. No sex over past } 5 \text { years } \\
\text { 2. Same-sex sex only over past } 5 \text { years (Homosexual) } \\
\text { 3. Same- and opposite-sex sex over past } 5 \text { years (Bisexual) } \\
\text { 4. Opposite-sex sex only over past } 5 \text { years (Heterosexual) }\end{array}$ & $\begin{array}{r}70 \\
47 \\
22 \\
1,798\end{array}$ & $\begin{array}{r}140 \\
28 \\
26 \\
1,529\end{array}$ \\
\hline
\end{tabular}

able only in broad categories in the GSS. We also restrict ourselves to a sample in which there are no missing values for earnings or for any of the independent variables.

Table 6 lists the sample sizes for various definitions of heterosexuality, homosexuality, and bisexuality. Our combined sample of the 1989-96 GSS contains 77 men and 53 women who are gay, lesbian, or bisexual by Badgett's definition of having had more same-sex than opposite-sex partners since age 18. Our samples of gays, lesbians, and bisexuals are somewhat smaller when based on current sexual behavior. Sixty men and 49 women are homosexual or bisexual by a definition that looks at the nature of sexual activity over the previous year; and 69 men and 54 women are homosexual or bisexual by a definition that uses sexual activity over the previous five years.

In Table 7, we present the key results from our earnings regressions. These regressions all include education, race, potential experience, potential experience squared, marital status, residence in a large city, and region of residence, but we report only coefficients for sexual orientation and marital status. In all cases we use "interval regression."

Column (1) reports the results when we use Badgett's definition of lesbian/bisexual and gay/bisexual. The regression uses all the GSS data from 1989-96. For women, the specification differs slightly from Badgett's original one, on which the regression coefficients presented in Table 2 and Table 3 are based. In the regressions presented here, we do not include the interaction term between lesbian/bisexual status and potential experience. Removing this variable enables us to interpret the coefficient on lesbian/bisexual status as the average effect over all levels of potential labor market experience. It also makes the regression specification for men and women identical. Recall that when we estimated the wage regression for women with the interaction term, we found that lesbian earnings were 0.06 higher than earnings of other women at the mean level of experience (though this point estimate was based on coefficients that were not statistically significant). This is precisely the same inference that one draws using the simpler specification that omits the interaction term. Results presented in column (1) for men are the same as those given in the second column of Table 2 .

Column (2) presents estimates of the effect of sexual orientation on earnings when homosexuality/bisexuality is defined 
Table 7. Effect of Sexual Orientation on the Logarithm of Annual Earnings, GSS Data, 1989-96. ${ }^{a}$

\begin{tabular}{|c|c|c|c|c|c|}
\hline \multirow[b]{2}{*}{ Variable } & \multirow{2}{*}{$\begin{array}{c}\text { Sexual Behavior } \\
\text { Since Age } 18 \\
\text { Bisexual } \\
\text { and } \\
\text { Homosexual } \\
\text { Combined } \\
\text { (1) }\end{array}$} & \multicolumn{2}{|c|}{$\begin{array}{l}\text { Sexual Behavior } \\
\text { over Past Year }\end{array}$} & \multicolumn{2}{|c|}{$\begin{array}{l}\text { Sexual Behavior } \\
\text { over Past } 5 \text { Years }\end{array}$} \\
\hline & & $\begin{array}{l}\text { Bisexual } \\
\text { and } \\
\text { Homosexual } \\
\text { Combined } \\
\text { (2) }\end{array}$ & $\begin{array}{c}\text { Homosexual } \\
\text { and } \\
\text { Bisexual } \\
\text { Separated } \\
\text { (3) }\end{array}$ & $\begin{array}{l}\text { Bisexual } \\
\text { and } \\
\text { Homosexual } \\
\text { Combined } \\
\text { (4) }\end{array}$ & $\begin{array}{c}\text { Homosexual } \\
\text { and } \\
\text { Bisexual } \\
\text { Separated } \\
\text { (5) }\end{array}$ \\
\hline \multicolumn{6}{|c|}{ Women } \\
\hline Lesbian or Bisexual & $\begin{array}{c}0.06 \\
(0.62)\end{array}$ & $\begin{array}{c}0.20 \\
(2.00)\end{array}$ & - & $\begin{array}{c}0.24 \\
(2.56)\end{array}$ & - \\
\hline No Sex & - & $\begin{array}{c}0.03 \\
(0.56)\end{array}$ & $\begin{array}{c}0.03 \\
(0.56)\end{array}$ & $\begin{array}{c}0.01 \\
(0.19)\end{array}$ & $\begin{array}{c}0.01 \\
(0.21)\end{array}$ \\
\hline Bisexual & 一 & - & $\begin{array}{c}0.13 \\
(0.60)\end{array}$ & - & $\begin{array}{c}0.12 \\
(0.92)\end{array}$ \\
\hline Lesbian & - & - & $\begin{array}{c}0.22 \\
(1.97)\end{array}$ & - & $\begin{array}{c}0.34 \\
(2.71)\end{array}$ \\
\hline Married & $\begin{array}{l}-0.03 \\
(-1.07)\end{array}$ & $\begin{array}{l}-0.03 \\
(-0.93)\end{array}$ & $\begin{array}{l}-0.03 \\
(-0.94)\end{array}$ & $\begin{array}{r}0.003 \\
(0.08)\end{array}$ & $\begin{array}{r}0.002 \\
(0.05)\end{array}$ \\
\hline Observations & 2,246 & 2,193 & 2,193 & 1,723 & 1,723 \\
\hline $\begin{array}{l}\text { Number of Lesbians } \\
\text { and Bisexuals }\end{array}$ & 53 & 49 & 49 & 54 & 54 \\
\hline \multicolumn{6}{|c|}{ Men } \\
\hline Gay or Bisexual & $\begin{array}{l}-0.21 \\
(-2.79)\end{array}$ & $\begin{array}{l}-0.16 \\
(-1.94)\end{array}$ & - & $\begin{array}{l}-0.14 \\
(-1.79)\end{array}$ & - \\
\hline No Sex & - & $\begin{array}{l}-0.16 \\
(-3.23)\end{array}$ & $\begin{array}{l}-0.16 \\
(-3.23)\end{array}$ & $\begin{array}{l}-0.25 \\
(-3.11)\end{array}$ & $\begin{array}{l}-0.25 \\
(-3.11)\end{array}$ \\
\hline Bisexual & - & - & $\begin{array}{l}-0.22 \\
(-1.07)\end{array}$ & - & $\begin{array}{l}-0.15 \\
(-1.06)\end{array}$ \\
\hline Gay & - & - & $\begin{array}{l}-0.15 \\
(-1.66)\end{array}$ & - & $\begin{array}{l}-0.14 \\
(-1.48)\end{array}$ \\
\hline Married & $\begin{array}{c}0.23 \\
(8.59)\end{array}$ & $\begin{array}{c}0.20 \\
(7.10)\end{array}$ & $\begin{array}{c}0.20 \\
(7.09)\end{array}$ & $\begin{array}{c}0.20 \\
(6.25)\end{array}$ & $\begin{array}{c}0.20 \\
(6.25)\end{array}$ \\
\hline $\begin{array}{l}\text { Observations } \\
\text { Number of Gays }\end{array}$ & 2,633 & 2,554 & 2,554 & 1,937 & 1,937 \\
\hline $\begin{array}{l}\text { Number of Gays } \\
\text { or Bisexuals }\end{array}$ & 77 & 60 & 60 & 69 & 69 \\
\hline
\end{tabular}

aThese are estimated coefficients from regressions in which the dependent variable is the logarithm of annual earnings. All specifications control for education, race, potential experience, potential experience squared, marital status, living in a large city, and region of residence. T-statistics are in parentheses.

Column explanations:

(2) Gays or bisexuals and lesbians or bisexuals had a same-sex sex partner over the past year.

(3) Gays or lesbians had only same-sex sex partners last year. Bisexuals had both male and female partners over the past year.

(4) Gays or bisexuals and lesbians or bisexuals had only same-sex sex partners over the past 5 years.

(5) Gays or lesbians had only same-sex sex partners over the past 5 years. Bisexuals had both male and female partners over the past 5 years.

as having had a same-sex sex partner within the past year. Column (3) distinguishes between homosexuality and bisexuality. Here homosexuality is defined as having had exclusively same-sex sex over the past year and bisexuality is defined as having had sex with both men and women over the past year. We also include in each of these regressions a dummy variable for individuals who have had no sexual activity over the 
past year. Columns (4) and (5) are estimated coefficients for regressions parallel to those presented in columns (2) and (3), but for the reference period of the past five years.

Coefficients reported in the last four columns show the estimated earnings effect of homosexual/bisexual orientation based on sexual behavior over the past year and the past five years-definitions that we have argued are likely more reflective of leading a gay or lesbian lifestyle. Consider first the definition of sexual orientation based on sexual behavior in the past year. We find that the negative effect of being a gay/bisexual man persists $(-0.16$ and statistically significant). Lesbian/bisexual orientation appears to raise earnings of women by about $20 \%$, a result that is both economically and statistically significant. When we separate women into those who engaged in exclusively same-sex sex (lesbian) and those who had engaged in sex with both men and women over the past year (bisexual), we continue to find that lesbian women have significantly higher earnings than other women.

Turning to definitions based on sexual behavior over the past five years, we again find that lesbian/bisexual women have substantially higher earnings. When we separate exclusively lesbian and bisexual behavior, the coefficient on lesbian orientation is in excess of 0.30 . For men, coefficients for gay/bisexual or gay and bisexual orientation separately are all close to -0.14 , although in the case where gay men are separated from bisexual men, the coefficient is not statistically significant.

We also report the effect of marriage on earnings for each model. Coefficients for marriage are never significantly different from zero for women. For men there is a substantial marriage premium, about $20 \%$, and this estimated effect is statistically significant. Interestingly, men with no sexual activity-especially those who have had no sexual activity for the past five years-have substantially lower earnings than other men.

In sum, our analysis of the GSS data indicates that typical (unmarried) gay men earn substantially less than married men, and the point estimate suggests that gay men also earn less than single heterosexual men, though this latter estimate is not always statistically significant. Lesbian women earn more than other women, both married and unmarried. Comparisons of estimates in column (1) and those given in columns (2)-(5) confirm that the different definitions of sexual orientation used substantially change inferences one draws about the relationship between sexual orientation and earnings.

At first glance it might seem clear that our results establish that the relationships between earnings and sexual orientation are not the consequence of simple discrimination whereby gay men and lesbian women alike face poorer job market prospects than their heterosexual counterparts. We must be cautious, however, in drawing even this inference. Wages do appear lower for gay men than for other men (especially married men), and the wage premium earned by lesbian women could conceivably be found even if lesbian women are discriminated against relative to other women. Because of career interruptions, potential experience is probably mismeasured. Even among women who are currently working full-time (that is, women in our sample), lesbian women may have had a stronger labor market commitment, and for any given level of potential experience may have more actual labor market experience. In the absence of more detailed data that include job histories, it is difficult to know how pronounced this effect might be. ${ }^{15}$

\section{The Role of Occupational Choice and Fertility}

Our specification does not allow us to investigate an interesting issue-the extent to which differences in earnings reflect differences in occupational choice by sexual orientation. As we discuss below, gender

\footnotetext{
${ }^{15}$ In on-going research, we are seeking to assemble other data that will allow us to examine this question more carefully.
} 
differences in occupational choice are often treated by economists as endogenousthe result of different choices men and women make in light of lifetime plans about childbearing and specialization in market versus home production. This same logic suggests that sexual orientation will affect occupational choice. For example, a lesbian woman, who understands that she is unlikely to partner with a (relatively highearning) man, may choose an occupation different from the one she would choose if she planned on getting married. Similarly, a gay man who believes he is unlikely to have children might choose an occupation different from the one he would choose if he planned on having a large family to support. Because occupational choice is thus likely to be endogenous, one must take care in interpreting estimated coefficients in a regression "controlling" for occupation. Nonetheless, it is interesting to see how important occupational choice is as a mechanism for shaping differences in earnings by sexual orientation. ${ }^{16}$

Table 8 provides additional specifications that shed some light on these two issues. Column (1) replicates our base specification using sexual behavior over the past 5 years as the basis for a definition of gay, lesbian, or bisexual (from column 5 of Table 7). Column (2) reports a specification that adds dummy variables for detailed occupation codes (these are 1980 3-digit Census occupation categories, which give over 100 different occupations in the GSS). We notice that this reduces the absolute value of the estimated lesbian and gay coefficients only slightly. In column (3) we report results for a regression in which we include also the number of children, and column (4) shows results for a regression that includes interactions between the num-

\footnotetext{
${ }^{16} \mathrm{By}$ the same token, many of the other variables included in our earnings regressions (and in earnings regressions more generally in the literature) are endogenous, including education, marital status, and even location (see Black, Gates, Sanders, and Taylor 2002).
}

ber of children and potential experience terms. Again, coefficients for the lesbian and gay variables change only modestly.

The inclusion of children and children/ experience in teractions is designed to control for the possibility that for women especially, "potential experience" will more accurately reflect actual experience for women without children than for women with children, and thus bias inferences about earnings differences between lesbian women and other women. As another way of investigating this latter issue, we estimated our key regressions (using the specifications in columns 3 and 5 from Table 7) for a sample of women who have never been married. We suspect that for most women in this group, both lesbian and heterosexual, actual work experience does not differ greatly from potential experience. We find that in these regressions, the coefficient on "lesbian" is 0.12 (t-statistic 0.77 ) when we use the definition that relies on sexual behavior in the previous year, and $0.36(\mathrm{t}$ statistic 1.84) when we use the definition that relies on sexual behavior in the past five years. In these regressions as well, then, there is no evidence that discrimination reduces the wages of lesbian women relative to other women. ${ }^{17}$

Our regressions implicitly make earnings comparisons between lesbians and other women and between gays and other men. We also examined a number of specifications comparing gay men's earnings with lesbian women's. For all definitions that we use to identify gays and lesbians, there were

\footnotetext{
${ }^{17}$ We should add that many women in our sample (both lesbian and heterosexual) have been previously married, so these inferences are being drawn from very small samples.

Another suggestive piece of evidence counter to the claim that lesbian women earn less than other women due to sexual orientation discrimination is that the largest positive wage effects we measure for lesbian women are for women who have had exclusively same-sex sex for the past five years. (See Table 7.) One might think that this group would be the most likely to be visible to employers as lesbian and would therefore be most easily subjected to discrimination.
} 
Table 8. Specifications That Control for Occupation and the Presence of Children.

\begin{tabular}{|c|c|c|c|c|}
\hline \multirow[b]{2}{*}{ Variable } & \multicolumn{4}{|c|}{ Sexual Behavior over the Past 5 Years } \\
\hline & $\begin{array}{c}\text { Baseline } \\
\text { Specification } \\
\text { (1) }\end{array}$ & $\begin{array}{l}\text { Add 3-Digit } \\
\text { Occupation } \\
\text { Codes } \\
\text { (2) }\end{array}$ & $\begin{array}{c}\text { Add } \\
\text { Occupation } \\
\text { Codes and } \\
\text { Children } \\
\text { (3) }\end{array}$ & $\begin{array}{l}\text { Add Occupation, } \\
\text { Children, and } \\
\text { Interactions of } \\
\text { Children and } \\
\text { Potential Experience } \\
\text { (4) }\end{array}$ \\
\hline \multicolumn{5}{|c|}{ Women } \\
\hline No Sex & $\begin{array}{c}0.01 \\
(0.21)\end{array}$ & $\begin{array}{l}-0.07 \\
(-1.26)\end{array}$ & $\begin{array}{l}-0.08 \\
(-1.43)\end{array}$ & $\begin{array}{l}-0.09 \\
(-1.59)\end{array}$ \\
\hline Bisexual & $\begin{array}{c}0.12 \\
(0.92)\end{array}$ & $\begin{array}{c}0.06 \\
(0.49)\end{array}$ & $\begin{array}{c}0.04 \\
(0.32)\end{array}$ & $\begin{array}{c}0.04 \\
(0.29)\end{array}$ \\
\hline Lesbian & $\begin{array}{c}0.34 \\
(2.71)\end{array}$ & $\begin{array}{c}0.30 \\
(2.42)\end{array}$ & $\begin{array}{c}0.28 \\
(2.32)\end{array}$ & $\begin{array}{c}0.26 \\
(2.16)\end{array}$ \\
\hline Married & $\begin{array}{c}0.002 \\
(0.05)\end{array}$ & $\begin{array}{c}-0.03 \\
(-1.08)\end{array}$ & $\begin{array}{l}-0.02 \\
(-0.65)\end{array}$ & $\begin{array}{c}-0.01 \\
(-0.44)\end{array}$ \\
\hline Number of Children & - & - & $\begin{array}{c}-0.04 \\
(-3.13)\end{array}$ & $\begin{array}{c}-0.01 \\
(0.86)\end{array}$ \\
\hline Children * Potential Experience $/ 10$ & - & - & - & $\begin{array}{l}-0.16 \\
(-3.43)\end{array}$ \\
\hline Children * Potential Experience Squared/100 & - & - & - & $\begin{array}{c}0.04 \\
(3.34)\end{array}$ \\
\hline $\begin{array}{l}\text { Observations } \\
\text { Number of Lesbian and Bisexuals }\end{array}$ & $\begin{array}{c}1,723 \\
54\end{array}$ & $\begin{array}{c}1,723 \\
54\end{array}$ & $\begin{array}{c}1,723 \\
54\end{array}$ & $\begin{array}{c}1,723 \\
54\end{array}$ \\
\hline \multicolumn{5}{|c|}{ Men } \\
\hline No Sex & $\begin{array}{c}-0.25 \\
(-3.11)\end{array}$ & $\begin{array}{c}-0.20 \\
(-2.58)\end{array}$ & $\begin{array}{l}-0.19 \\
(-2.43)\end{array}$ & $\begin{array}{l}-0.16 \\
(-1.98)\end{array}$ \\
\hline Bisexual & $\begin{array}{c}-0.15 \\
(-1.06)\end{array}$ & $\begin{array}{c}-0.09 \\
(-0.62)\end{array}$ & $\begin{array}{l}-0.07 \\
(-0.52)\end{array}$ & $\begin{array}{c}-0.07 \\
(-0.48)\end{array}$ \\
\hline Gay & $\begin{array}{c}-0.14 \\
(-1.48)\end{array}$ & $\begin{array}{c}-0.13 \\
(-1.34)\end{array}$ & $\begin{array}{l}-0.12 \\
(-1.24)\end{array}$ & $\begin{array}{l}-0.12 \\
(-1.28)\end{array}$ \\
\hline Married & $\begin{array}{c}0.20 \\
(6.25)\end{array}$ & $\begin{array}{c}0.17 \\
(5.51)\end{array}$ & $\begin{array}{c}0.16 \\
(4.91)\end{array}$ & $\begin{array}{c}0.16 \\
(5.03)\end{array}$ \\
\hline Number of children & - & - & $\begin{array}{c}0.02 \\
(1.89)\end{array}$ & $\begin{array}{c}0.03 \\
(1.73)\end{array}$ \\
\hline Children * Potential Experience $/ 10$ & - & - & - & $\begin{array}{l}-0.12 \\
(-2.45)\end{array}$ \\
\hline Children * Potential Experience Squared $/ 100$ & - & - & - & $\begin{array}{c}0.04 \\
(2.84)\end{array}$ \\
\hline Observations & 1,937 & 1,937 & 1,937 & 1,937 \\
\hline Number of Gays and Bisexuals & 69 & 69 & 69 & 69 \\
\hline
\end{tabular}

These are estimated coefficients from regressions in which the dependent variable is the logarithm of annual earnings. All specifications control for education, race, potential experience, potential experience squared, marital status, living in a large city, and region of residence. T-statistics are in parentheses.

no statistically significant earnings differences between the two groups.

Of course, all the inferences we have drawn are subject to a serious concern about the quality of the data. In particular, our definitions of sexual orientation depend on the accuracy of responses about gender and about sexual behavior. In a working 
paper, we show that misreported gender is a potentially serious concern, but that in fact such misreports probably do not drive the main results reported here. ${ }^{18}$ We cannot, however, discount the possibility that some individuals give incorrect responses about their sexual behavior, and that this misreporting is correlated with earnings.

\section{Discussion}

This paper provides new empirical evidence on the relationship between sexual orientation and earnings. Using simple earnings regressions, we find that lesbian women earn more than comparable single and married women, while gay men earn less than their married male counterparts and also perhaps somewhat less than comparable single heterosexual men. The appropriate interpretation of these findings is not obvious.

In the preceding pages we outlined one economic model that can be used as a framework for rationalizing these findings without relying on discriminationBecker's model of household specialization. In this theory, many young people make human capital investments based on the expectation that they will form traditional households in which the husband and wife will specialize differentially in market and non-market production. Becker argued that men who remain single (including, presumably, many gay men) should be expected to earn less than similar married men because these single men specialize less intensely in market production.

In short, in comparison to married and single heterosexual men, gay men will devote fewer personal resources to careerrelated investments. This may appear in the form of different levels of observed schooling, but may be even more likely to affect unobservable dimensions of individuals' careers, including willingness to accept objectionable working conditions for higher compensation. If heterosexual men antici-

\footnotetext{
${ }^{18}$ See Black, Makar, Sanders, and Taylor (2000).
}

pate having to support a family, they may be more willing than gays to accept transfers, accept jobs that are more stressful, or work longer hours. This may contribute substantially to observed earnings differences.

Becker also argued that unmarried women will typically earn more than comparable married women because unmarried women will specialize less in non-market production (for example, unmarried women are less likely to make decisions based on family commitments that compromise their careers). Many of these unmarried women, however, will have made human capital investment decisions based on an expectation of marriage and specialization in non-market production, and these women will therefore earn less than comparable single men. Under this theory, lesbian women on average would earn more than other women, because many lesbians will have made human capital investments and labor market decisions with the understanding that they are unlikely to form traditional households in which they specialize in non-market production.

The logical structure here is simple: sexual orientation is taken as essentially exogenous. Individuals who are gay or lesbian face constraints different from those facing other men and women, and therefore make different optimal choices over important dimensions of their lives. Some of these differences affect labor market outcomes in ways that are not completely captured by the limited human capital measures available in our data. Thus, sexual orientation appears as an important variable in earnings regressions.

In thinking about this interpretation, we find it helpful to refer to Table 9 . This table reports the educational distribution of gay men and their fathers, and, for comparison, the corresponding distributions for heterosexual men. It is immediately apparent that the distribution of fathers' education is virtually the same for gay men as for heterosexual men. Although gay men are born and raised in households that are similar to those of heterosexual men (at least along the dimension of father's education), however, they differ markedly from 
heterosexuals in their own educational choices. ${ }^{19}$ This outcome is consistent with two conjectures. First, sexual orientation is not determined by family characteristics, and thus differences between gay men and heterosexual men in labor market outcomes are not due to systematic differences in family backgrounds. Second, sexual orientation does have an independent meaningful effect on observed choices such as education, and thus likely has effects on other unobservable choices that could also affect labor market outcomes. On the other hand, the fact that gay men obtain higher schooling levels than heterosexual men is inconsistent with the notion that gay men place less emphasis than other men on their labor market earning power.

Although we view the results presented in this paper as reasonably consistent with Becker's theory of household specialization and human capital accumulation, there is a complementary way of thinking about our results that places less emphasis on the role of individual choice, and emphasizes instead the role of discrimination in labor markets. Perhaps the low wages of gay men, relative to other men, are due not only to differences in specialization and other labor market choices, but also to deep and pervasive anti-gay attitudes of employers (documented by Miller [1995], D’Emilio [1983], and many other scholars). The

\footnotetext{
${ }^{19}$ Differences between educational levels of gay men and heterosexual men are not due to differences in the age distribution of these groups. (Simple age adjustments make virtually no difference in Table 9.) Unfortunately, the sample size of lesbian women who report their father's highest degree is too small (46) to draw conclusions about the distribution of fathers' education for these women compared to other women.

It is worth noting that this exercise also provides modest evidence against the possibility that the relatively high observed level of education among the gay men in our sample is simply the consequence of more poorly educated gay men being relatively reluctant to report having had same-sex sex. More generally, willingness to report same-sex sexual activity may be selectively endogenous in ways that matter for our study. It is important to remember that our $\mathrm{L} / \mathrm{B} / \mathrm{G}$ definitions are all based on self-reports.
}

difficulty with that explanation, of course, is that lesbian women earn more than heterosexual women, which seems inconsistent with the notion of employers discriminating on the basis of sexual orientation.

The analysis, however, is somewhat more complicated if heterosexual women face discrimination as well. If heterosexual women know that they will face discrimination in the marketplace, and that this discrimination will increase when they marry, they will lower their investment in human capital for the labor market and allow their spouses to specialize in the labor market. Lesbians, who know they will not marry, would invest more in human capital for the labor market, as they expect to be partnered with someone facing discrimination as well. Single heterosexual women, some of whom anticipate being married, would also invest less than lesbians in human capital for the labor market.

In her well-known book, Understanding the Gender Gap: An Economic History of American Women, Goldin (1990) documented the extent to which women in the early twentieth century generally faced difficult decisions about families and careers. Many firms and school districts had policies to avoid hiring married women and to fire single women when they married. Employers also frequently adopted the practice of refusing to hire women with small children or firing women when they became pregnant. These "marriage bars" and "pregnancy bars" were the most visible of the explicit and implicit restrictions imposed to "protect" women, whose proper role was seen as being in the home. It is hardly surprising that in a milieu in which such paternalistic social norms were openly accepted and enforced, few women could balance both family and professional careers. Goldin (1997) noted that of women graduating from college in the United States around 1910, about 50\% either did not marry or had childless marriages. While successive cohorts of twentieth-century female college graduates did marry and have children at higher rates, they nonetheless to varying degrees continued to face similarly difficult family career choices. 
Table 9. Distribution of Own Education and Father's Education for Gay and Heterosexual Men. ${ }^{\mathrm{a}}$

\begin{tabular}{|c|c|c|c|c|}
\hline \multirow[b]{2}{*}{ Education Level } & \multicolumn{2}{|c|}{ Own Education } & \multicolumn{2}{|c|}{ Father's Education } \\
\hline & Gay Men & Heterosexual Men & Gay Men & Heterosexual Men \\
\hline High School or Less & 0.35 & 0.47 & 0.67 & 0.70 \\
\hline Some College & 0.28 & 0.28 & 0.13 & 0.13 \\
\hline BA & 0.24 & 0.16 & 0.13 & 0.10 \\
\hline MA & 0.13 & 0.09 & 0.07 & 0.07 \\
\hline Observations & 106 & 4,128 & 80 & 3,226 \\
\hline (weighted observations) & $(100)$ & $(4,438)$ & $(76)$ & $(3,474)$ \\
\hline
\end{tabular}

${ }^{\mathrm{a}}$ Gay is defined as having exclusively male sexual partners over the past year, heterosexual as having exclusively female sexual partners over the past year. Data are from the GSS, weighted to the adult population.

Ironically, the paternalistic form of gender discrimination Goldin describes may have adversely affected lesbian women less than other women, as the former, many of whom were free of the socially important constraint of having husbands and children, had greater freedom to pursue career objectives. It seems likely that many lesbian women, in those circumstances, would have accumulated human capital and made other career decisions that improved their relative position in the labor market. Given that many discriminatory practices against women focused on women who were married or had children (or both), lesbians may often have been simply "overlooked." This in turn could be a contributing factor to the currently observed labor market success of lesbian women relative to other women. ${ }^{20}$

\footnotetext{
${ }^{20} \mathrm{An}$ interesting case in point is military policy toward gays and lesbians as it developed in the 1940s. During World War II, the military for the first time implemented a formal policy excluding homosexuals, and explicitly asked recruits about sexual orientation. Gay servicemen could be given "blue discharges" (neither honorable nor dishonorable) and banned from receiving veterans' benefits even if they had committed no known sexual acts while in the military. The experience for lesbians was quite different. Essentially, lesbian women were overlooked; procedures to screen out lesbians were not put into place until October 1944. (See, for example, Miller 1995.) Instead, the military had in place restrictive paternalistic criteria of the sort Goldin documents for the private sector: married women were not allowed to
}

Our central point here is that social and economic processes that operate in labor markets are especially complicated for women. As Goldin (1990) wrote, "The progress of women's work is like none other in the labor market. It cannot be understood as an isolated market responding to economic factors, as most other economic variables can. Rather, it is tied, as is each woman, to the home, the family, and the process of socialization, and is linked by each woman to her past and her future through the life cycle." Given the complexities of women's involvement in labor markets and of discriminatory practices that adversely affect women, lesbian earnings may not be affected in an "additive" manner by pervasive gender bias and sexual

enlist, and women who became pregnant were immediately discharged. It is not surprising that a large number of lesbian women served in the military in World War II. Indeed, D'Emilio (1983) describes the Women's Army Core as an "almost quintessential lesbian institution” (p. 27). Interestingly enough, then, though the army was an organization that had explicit discriminatory policies both against women and against homosexual people generally, these policies interacted in a way that allowed many lesbian women to be relatively successful.

Although the U.S. military continues to have policies explicitly discriminating on the basis of sexual orientation, data from both the GSS and Census indicate that the ratio of lesbians to heterosexual women in the military greatly exceeds that ratio in the population at large. (See Black et al. 2000.) 
orientation bias; lesbian women may not invariably earn less than other women. If the conjectures we have just outlined are correct, our results with respect to lesbian earnings may have little to say about the nature of discrimination against homosexual individuals generally and instead may shed light on the pervasive nature of gender roles and social norms in labor markets.

\section{REFERENCES}

Allegretto, Sylvia A., and Michelle M. Arthur. 2001. "An Empirical Analysis of Homosexual/Heterosexual Male Earnings Differentials: Unmarried and Unequal?" Industrial and Labor Relations Review, Vol. 54, No. 3 (April), pp. 31-46.

Badgett, M. V. Lee. 1995. "The Wage Effects of Sexual Orientation Discrimination." Industrial and Labor Relations Review, Vol. 48, No. 4 (July), pp. 72639.

Becker, Gary S. 1971. The Economics of Discrimination, 2nd ed. Chicago: University of Chicago Press. 1981. A Treatise on the Family. Cambridge, Mass.: Harvard University Press.

Berg, Nathan, and Donald Lien. 2002. "Measuring the Effect of Sexual Orientation on Income: Evidence of Discrimination?" Contemporary Economic Policy, Vol. 20, No. 4 (October), pp. 394-414.

Black, Dan, Gary Gates, Seth Sanders, and Lowell Taylor. 1999. "Why Do Gays Live in San Francisco?" Unpublished paper, Carnegie Mellon University. 2002. "Why Do Gays Live in San Francisco?" Journal of Urban Economics, Vol. 51, No. 1, pp. 54-76. Black, Dan, Hoda Makar, Seth Sanders, and Lowell Taylor. 2000. "The Effects of Sexual Orientation on Earnings." Working paper, Syracuse University.

Blumstein, Phillip, and Pepper Schwartz. 1983. American Couples. New York: William Morrow.
Daniel, Kermit 1996. "Does Marriage Make Workers More Productive?" Unpublished paper, University of Pennsylvania.

D’Emilio, John. 1983. Sexual Politics, Sexual Communities. Chicago and London: University of Chicago Press.

Goldin, Claudia. 1990. Understanding the Gender Gap: An Economic History of American Women. New York: Oxford University Press.

1997. "Career and Family: College Women Look to the Past." In Francine Blau and Ronald Ehrenberg, eds., Gender and Family Issues in the Workplace. New York: Russell Sage Foundation.

Kinsey, Alfred C., Wardell B. Pomeroy, Clyde E. Martin, and Paul H. Gebhard. 1948. Sexual Behavior in the Human Male. Philadelphia: Saunders.

Klawitter, Marieka. 1997. "The Effects of Sexual Orientation on the Determinants of Earnings for Women." Unpublished paper, University of Washington.

Laumann, Edward O., John H. Gagnon, Robert T. Michael, and Stuart Michaels. 1994. The Social Organization of Sexuality: Sexual Practices in the United States. Chicago: University of Chicago Press.

Miller, Neil. 1995. Out of the Past: Gay and Lesbian History from 1869 to the Present. New York: Vintage. 